Pilar Concheiro

UNIVERSITY OF ICELAND

\title{
Telecollaboration HI-UB: online interaction and exchange in a language course
}

\section{Introduction}

The aim of this article is to offer a comprehensive mapping and description, followed by an analysis of the course SPÆ267G Conversation II or Talbjálfun II: Fjölmiðlar og bversdagsmenning, taught at the Faculty of Languages and Cultures at the University of Iceland (HI) and partner in a virtual exchange project with the University of Barcelona. Issues such as task designing and the evaluation system will be presented, while subsequently, in the results section, through a qualitative approach, an analysis of HI students' reflections about the project itself and its impact on their language competence is introduced and discussed.

The context of the study is a virtual exchange program ${ }^{1}$ between Icelandic learners of Spanish as a foreign language from the University of Iceland (HI) and teacher trainees of Spanish studying for their Master's degree at the University of Barcelona (UB). The virtual exchange project, called Telecollaboration HI-UB took place during the 2019 spring semester. Although this article focuses only this particular course, the UB has carried out several similar projects in collaboration with the University of Groningen in the Netherlands since

1 Robert O’Dowd. (2018). "From Telecollaboration to Virtual Exchange: State-of-the-art and the Role of UNICollaboration in Moving Forward." Journal of Virtual Exchange, 1, pp. 1-23. Researchpublishing.net. 
2013 and with the University of Iceland since the academic year 2016-2017. The participants were 22 Spanish pre-service teachers from the University of Barcelona studying the subject ICT (Information and Communication Technology) in the teaching of Spanish as a foreign language and 11 students of Spanish as a foreign language at the University of Iceland. This telecollaboration project was based on different communicative tasks that had to be completed collaboratively using different formats of interaction (videoconferencing, WhatsApp, Flipgrid). Moreover, Google classroom was used as a virtual environment for the project participants from both educational institutions, which means that all the documents, calendar, task instructions and products created were shared there and both students and teachers could have easy access to them. The teachers in charge of the project were Dr. Joan Tomás Pujolá and Dr. Olivia Espejel from the University of Barcelona and Dr. Pilar Concheiro from the University of Iceland. This project started thanks to a personal initiative and contact and not through any institutional arrangement. It must be noted that the project was carried out in parallel - and was deeply imbricated - with the development of the classes of each group from January to April 2019. Consequently, for the students of Spanish as a foreign language at the University of Iceland, the telecollaboration project made up $50 \%$ of the final grade, while it represented $80 \%$ of the final grade for the pre-service teachers at the UB. Furthermore, much of the content used during face to face classes at HI was based on the virtual exchange project. All the multimodal products $^{2}$ generated during the project were incorporated into the weekly class and used as input for language and intercultural learning. The three teachers in charge of the project agreed that the virtual exchange had to be integrated into the courses at $\mathrm{HI}$ and the UB and be evaluated as credit-bearing activities.

For clarification, this project can be typified as 2.0 telecollaboration $^{3}$ since it emphasizes the development of digital competences, specially concerning digital communicative and intercultural compe-

2 In virtual exchanges, different communication channels can be used to create a learning space where elements such as sound, images, emojis are used to foster communication and interaction (Cope et al., 2011).

3 Sarah Guth and Francisca Helm (Eds.). (2010). Telecollaboration 2.0. Language, Literacies and Intercultural Learning in the 21st century. New York: Peter Lang. 
tences. In addition, the group of students of Spanish at HI was expected to develop their linguistic competence through the different tasks and the help and support of the pre-service teachers at the UB.

\section{Telecollaboration in higher education}

Virtual exchange, also known as telecollaboration or Collaborative Online International Learning (COIL), is a term used to describe different methods of engaging students in online intercultural collaboration projects with partner classes within their programmes of study and under the guidance of teachers or trained facilitators. ${ }^{4}$ The exchange is based on student-centred, international, and collaborative approaches to learning where knowledge is built up and shared through interaction. This approach has been used in higher education for more than 20 years ${ }^{5}$ and has been used widely in subject areas such as foreign language education, business studies, and initial teacher education. ${ }^{6}$ As Luo and Yang $^{7}$ hold, the development of Internet technology makes direct communication between foreign language learners and native speakers more possible than before. Web 2.0 technologies have opened new horizons for language learning and teaching involving intercultural exchanges. ${ }^{8}$ With the rise of Web 2.0, a wide range of communication tools has emerged, such as blogging, podcasting, wikis, and social networking sites (e.g. Twitter, Facebook, Instagram), creating a new generation of telecollaborative exchanges.' Concerning its effect on the learning process, various

4 Robert O'Dowd and Tim Lewis (Eds.). (2016). Online Intercultural Exchange: Policy, Pedagogy, Practice. Routledge Studies in Language and Intercultural Communication. Routledge.

5 Mark Warschauer (Ed.). (1996). Telecollaboration in Foreign Language Learning. Honolulu, HI: University of Hawaii. Second Language Teaching and Curriculum Center.

6 Robert O'Dowd. (2018). "From Telecollaboration to Virtual Exchange: State-of-the-art and the role of UNICollaboration in Moving Forward," 1, pp. 1-23.

$7 \quad$ Han Luo and Chunsheng Yang (2018). "Twenty Years of Telecollaborative Practice: Implications for Teaching Chinese as a Foreign Language." Computer Assisted Language Learning, 31, pp. 546 571.

8 Lina Lee. (2009). "Promoting Intercultural Exchanges with Blogs and Podcasting: A Study of Spanish American Telecollaboration." Computer Assisted Language Learning, 22 (5), pp. 425-443.

9 Sarah Guth and Francesca Helm (Eds.). (2010). Telecollaboration 2.0. Language, Literacies and Intercultural Learning in the 21st century. 
types of beneficial outcomes of telecollaboration have been reported. For example, online exchanges have been found to be able to improve grammatical competence, ${ }^{10}$ fostering lexical capacity ${ }^{11}$ and enhancing oral communication skills. ${ }^{12}$ Moreover, tellecolaborative practices could help to promote learner autonomy, ${ }^{13}$ develop digital literacies ${ }^{14}$ and motivate the building of learning communities. ${ }^{15}$

For the purpose of this study, it becomes relevant to introduce different models of virtual exchange projects and for this study the pre-service teachers interacted with students of a foreign language (Spanish) and encouraged them to develop their language skills using technologies in an innovative way. At the same time, pre-service teachers were prompted to apply the necessary skills and competences to teach in a culturally diverse context such as Iceland with a multicultural and multilingual group. ${ }^{16}$ Between 2017-2018 the Evaluating and Upscaling Telecollaborative Teacher Education (EVALUATE) project organized virtual exchanges which involved over 1000 students becoming the first large scale study in this field. The conclusions and implications of the EVALUATE study ${ }^{17}$ maintain that class to class virtual exchange is a potent tool for promoting innovation and international learning in the university classroom. Engaging students in structured online telecollaboration as part of their formal learning

10 Helmut Brammerts. (1996). "Language Learning in Tandem Using the Internet." In Mark Warschauer (Ed.). Telecollaboration in Foreign Language Learning, pp. 121-130. Lina Lee. (2002). "Enhancing Learners'Communication Skills Through Synchronous Electronic Interaction and Task-based Instruction.” Foreign Language Annals, 35(1), pp. 16-24.

11 Paola E. Dussias. (2006). "Morphological Development in Spanish-American Telecollaboration." In Julie A. Belz and Steven L. Thorne (Eds.). Internet-mediated Intercultural Foreign Language Education, pp. 121-146. Boston: Thomson Heinle.

12 Zsuzsanna I. Abrams. (2003). "The Effects of Synchronous and Asynchronous CMC on Oral Performance in German." Modern Language Journal, 87(2), pp. 157-167. Robert Blake. (2000). "Computer Mediated Communication: A Window on Spanish L2 Interlanguage." Language Learning E Technology, 4(1), pp. 120-136.

13 Klaus Schwienhorst. (2000). Virtual Reality and Learner Autonomy in Second Language Acquisition (Unpublished doctoral dissertation). Dublin, Ireland: Trinity College Dublin.

14 Francesca Helm. (2014). “Developing Digital Literacies Through Virtual Exchange.” Elearning Papers, 38, pp. 1-10.

15 Lina Lee. (2006). “A Study of Native and Nonnative Speakers' Feedback and Responses in Spanish-American Networked Collaborative Interaction." In Julie A. Belz and Steven L. Thorne (Eds.), Internet- mediated Intercultural Foreign Language Education, pp. 147-176.

16 Students were not just from Iceland.

17 The EVALUATE group. (2019). Evaluating the Impact of Virtual Exchange on Initial Teacher Education: A European Policy Experiment. Research-publishing.net https://www.evaluateproject.eu/ evlt-data/uploads/2019/03/EVALUATE_EPE_2019.pdf [accessed July 31st, 2019]. 
has been proven to contribute to the enhancement of students' digitalpedagogical, intercultural and foreign language competences.

\section{Methodology}

For further clarification, and as already explained, the student group from the University of Iceland was registered for the course Conversation II or Talpjálfun II: Fjölmiðlar og hversdagsmenning. Their language proficiency level could be described as B1-B2 corresponding to The Common European Framework of Reference for Languages. ${ }^{18}$ The group of trainee teachers from the UB studied the subject ICT for Spanish Teaching and had no previous experience in online teaching or telecollaboration. Both groups' demographics are summarized in Table 1 below

\begin{tabular}{|lll|}
\hline $\begin{array}{l}\text { Number } \\
\text { of students }\end{array}$ & HI & \multicolumn{2}{c|}{ UB } \\
Gender & 8 females -3 males & 17 females -5 males \\
Origin & 5 Icelandic, 1 Albanian/Icelandic & 17 Spanish, 2 Peruvian, \\
& $\begin{array}{l}\text { 1 Lithuanian/Icelandic, } \\
\text { 1 Russian, 1 Norwegian, 1 USA }\end{array}$ & $\begin{array}{l}\text { 1 French1 Argentinian, 1 German } \\
\text { Age }\end{array}$ \\
& Ranges from 21 to 45 & Ranges from 20 to 28 \\
& & \\
\hline
\end{tabular}

Table 1. Demographics of both groups of students

The three professors involved had access to all the content created by both groups of students. The conversations organized via Skype and Hangouts were recorded by the students themselves (tutorials at the beginning of the course were offered to assist them with this task). Furthermore, WhatsApp conversations were also handed in and finally any product created through the social web was shared. Concerning instant messaging applications and taking into account

18 Council of Europe. (2001). Common European Framework of Reference for Languages: Learning, Teaching, Assessment. Cambridge, U.K: Press Syndicate of the University of Cambridge. 
that messaging was used by the two groups to interact and communicate among themselves beyond the didactic tasks proposed, before sharing the conversations' back up, students were allowed to delete any content not strictly related to the tasks or topics. Before starting the project, students also signed a consent form and gave permission to the professors at the UB and at HI to use video, text, image and audio recordings (with personal identifying information rendered anonymous) as part of the research study on the current telecollaboration project in which they were participating.

A qualitative approach of analysis of the reflective diaries by the $11 \mathrm{HI}$ students was carried out in order to analyze the impact of the virtual exchange project on students' linguistic competence. The four indicators taken into account were: lexical and grammatical competence; pronunciation, fluency and confidence.

\section{Project description and task designing}

The HI-UB telecollaboration project formed part of blended-learning set-ups ${ }^{19}$ where virtual activities and online interaction with foreign partners were closely integrated into the activities which went on during face-to-face class time. Compared to traditional classroom-based task activities, telecollaborative tasks, involving speakers of different languages and cultural backgrounds, have a natural tendency of producing negotiation of meaning and providing opportunities for the exploration of different cultural perspectives. ${ }^{20}$

The task designing was based on the Progressive Exchange Model. ${ }^{21}$ The model proposes "three interrelated tasks which move from information exchange to comparing and analysing cultural practices and finally to working on a collaborative product" (p.40) (see Figure 1).

19 Sarah Guth and Francesca Helm. (2011). "Developing Multiliteracies in ELT Through Telecollaboration.” ELT Journal, 66 (1), pp. 42-52.

20 Robert O’Dowd. and P. Ware. (2009). “Critical Issues in Telecollaborative Task Design." Computer Assisted Language Learning, 22 (2), pp. 173-188, here p.175.

21 Robert O’Dowd. (2017). "Exploring the Impact of Telecollaboration in Initial Teacher Education: The EVALUATE Project." The EUROCALL Review, 25 (2), pp. 38-41. 


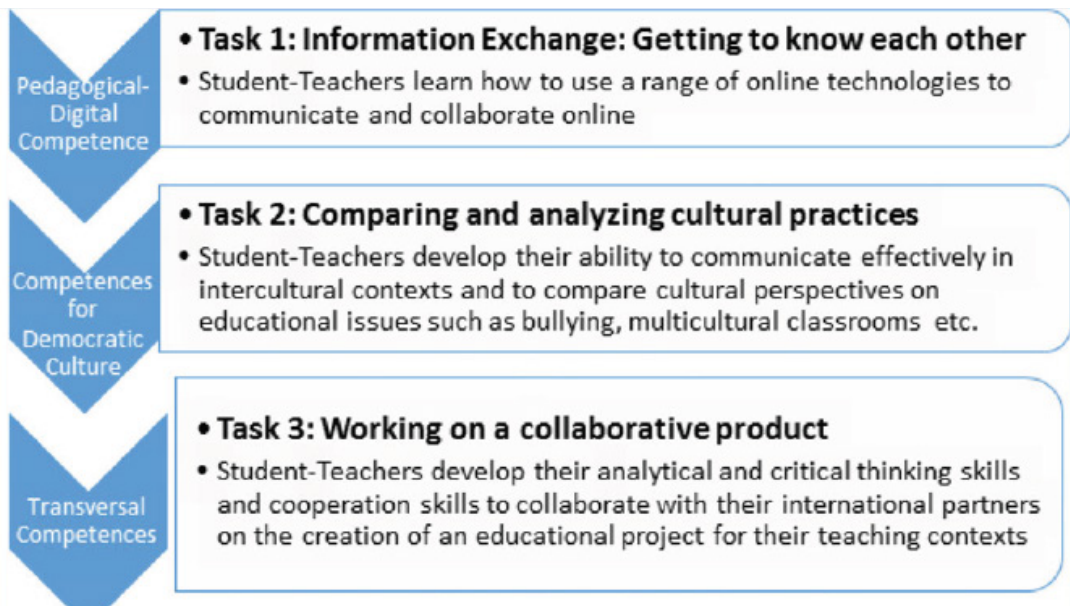

Figure 1. Progressive Exchange Model (O’Dowd, 2017)

Therefore, the Telecollaboration HI-UB project was divided into two phases. During the first phase the professors of both universities indicated three tasks that the students had to carry out jointly and collaboratively. They provided them with instructions and guidelines that should be followed. In the second phase, the students of the University of Barcelona became active agents and were in charge of designing a 2.0 project for their colleagues in Iceland taking into account their needs and interests in order to develop a meaningful learning context. The two project parts and the tasks followed a calendar created by the teachers of the UB and HI. The calendar was compatible with both institutions' academic year and also considered the time necessary to perform every task. For the first three, an average of 10 days was used per task; however, for the accomplishment of the final project, HI students had five weeks as more time was needed to plan this type of project. The UB students had 10 days to design the final project under the guidance and supervision of the 3 teachers involved. They had to present and share their drafts with their colleagues and teachers at the UB and after getting the first feedback they had to send the projects to the teacher at UI who reviewed them and sent them back to them with comments and suggestions. Afterwards, they would present them again at the UB before getting the green light. It is worth noting that some groups 
needed more guidance than others so constant communication and assistance was provided by the teachers at the UB and UI. For clarification, in the following subsections, a more detailed task description is presented. All the tasks described in section 4 were carried out outside the classroom autonomously. However, all the course contents and the activities carried out inside the classroom were closely related to the telecollaboration project. For example, in order to prepare for the telecollaboration task 1 , during class time students practiced linguistic structures related to introducing themselves. A part of every face-to-face class would be dedicated to the telecolaboration project as the teacher would explain carefully what the students would have to do, follow up the calendar and talk to the students about how the project was going in order to check any problem that could arise.

\subsection{Task 1. Getting to know each other}

The first task of the project consisted of a video recording introduction using Flipgrid as a way to start getting to know each other and as a preliminary activity for the first one-to-one video conferencing encounter. Flipgrid (https://flipgrid.com/) is a video discussion platform where teachers create a grid on a topic and students, using any mobile devices, can upload short videos (up to 90 seconds in the free version) responding to the topic. Flipgrid was used as a way to start getting to know one another and as a preliminary task before the first one-to-one video conferencing encounter. UB students had to introduce themselves inviting HI students to choose them as future partners. On their behalf, HI students had to watch all videos and record a message responding to their three favourite ones. It is worth mentioning that students at the University of Iceland reported in their post-task reflections that they had been very careful about not leaving any student from the UB without a video answer. This fact shows how HI students were trying to create a pleasant learning atmosphere from the beginning and how careful they were about avoiding negative feelings. Furthermore, this first contact using the video grid helped to reduce the foreign language learners' anxiety, 
provided a good emotional atmosphere and fostered their motivation towards the telecollaboration project. ${ }^{22}$

As the group at HI was smaller than the one at UB, each $\mathrm{HI}$ student was paired with one or two UB students for this first task. The following week, HI students were asked to have a videoconference using Skype or Google Hangouts with their partner or partners. They were asked to share personal pictures related to different times in their lives (in order to encourage them to talk about a meaningful topic). This was used as an ice-breaking task but also allowed UB students to perform a needs analysis, ${ }^{23}$ which means that they could find out what HI students needed to improve (vocabulary acquisition, grammar accuracy, pronunciation and intonation and so on) so that they could accordingly could take action and design activities that would help the students in Iceland to improve.

\subsection{Task 2. Everything you always wanted to know about ...}

The communication channel for this task was conducted through the WhatsApp messaging service. The main objective consisted in the exploration of forms of multimodal communication and its teaching. The first step of this task consisted in establishing a discussion to choose a sociocultural theme about the other students' countries and cultures that might have aroused their curiosity and interest. Once these topics were identified, the students paired up and divided in groups of 4 (two students from the UB and two from HI) in order to create a short video about the chosen topic and share it with their classmates from the other university. As they were using WhatsApp, the supervisor teachers recommended the students to record videos with a length that would suit this messaging service, which means between 3 and 4 minutes.

The pre-service teachers also had to consider possible didactic explorations that could be carried out through these visual narratives.

22 J. T. Pujolá, O. Espejel and P. Concheiro. (2019). "First Encounters in a Virtual Exchange Project: Analysis of Students' Interactions and Their Reflections." Proceedings Social CALL, pp. 227-235. The Education University of Hong Kong. file://C:/Users/mdc/Documents/proceedings\%20 CALL\%202019_DEF.pdf_[accessed November 17th, 2019].

23 A need analysis tries to get information on the situations in which a language is going to be used and the purposes for which that language is needed. This can vary from one student to another. 
Finally, through another videoconference in Google hangouts, the UB students gave linguistic feedback to their partners in Iceland and discussed the cultural questions that had arisen. The themes presented in the videos covered wide ranging topics, such as: gastronomy, traditions and the everyday life of a university student. In some cases, the students employed their sense of humor, which brought freshness to their proposals and showed the relaxed atmosphere generated among the group members. It is worth nothing that students from both universities went beyond the task and continued to chat on WhatsApp about the videos they had created, maintaining a conversation that transcended the classroom and the strictly academic task.

\subsection{Task 3. ¿Whatsapeamos?}

The last task designed for the purpose of this study presents a continuity of the previous one since it shares its main goals, i.e. to explore forms of multimodal communication and its teaching, and the same communication channel (WhatsApp). On this occasion, the pre-service teachers were in charge of proposing three small activities to their Icelandic colleagues; they had to design them taking into account the needs of HI students and the communicative potential for teaching foreign languages through this messaging application. UB pre-service teachers were taught by their tutors at UB what a language needs analysis is and how relevant it is for a language teacher. This aspect was part of their course and they had to read a bibliography and reflect on it.

Those activities that we mentioned had to be short and engaging; they had to incorporate the application into the students' lives in order to create and foster interaction. The pre-service teachers had to make the most out of this application for task designing and as a pedagogical tool. They were in charge of creating a learning space where different affordances as text, audiovisual and kineticons (images, animated gifs, emoticons, emojis) could allow HI students to express themselves in the target language and improve their communicative competence. An example of a micro-activity proposed by pre-service teachers using WhatsApp consisted of asking a simple question like "where are you now? send me a picture." The question 
acted as a trigger and students from both universities started chatting about their everyday lives and comparing them from an intercultural perspective. Topics like meals schedules, working hours after school and family conciliation appeared in the conversations. Another example of task designing included gamification ${ }^{24}$ components: the pre-service teachers at the UB created a game in which the HI students had to guess the titles (in Spanish) of famous movies just by using emoticons. This emoticon 国帮 would represent the film The Jungle Book that was translated in Spanish as "El libro de la selva". An extract from the conversation hold by the students (HI1 and HI2 are the students from the University of Iceland; UB1 and UB2 are the students from the University of Barcelona) playing the game, though the instant messaging application has been included (see translation in English ${ }^{25}$ ):

HI1: Me gusta mucho esto juego

HI2: a mi también

UB1: Para encontrar el nombre de la película en español podéis consultar Internet o las fuentes que queráis

[...]

UB12: EMPIEZA!

UB1: 四T

HI1: Isla del tesoro

HI2: Náufrago?

UB2: Incorrecto! Vuelve a intentarlo!

HI2: el arból de la vida

UB1: Incorrecto

HI1: Libro de la vida?

HI2: el libro de la selva

UB1: CORRECTO!

UB2: HI2, tienes 1 punto!

24 The application of typical elements of game playing (e.g. point scoring, competition with others, rules of play) to other areas of activity.

25 HI1: I really like this game/HI2: me too/UB1: In order to find out the film's name you can use Internet and search for it there/UB2: WE START!/UB1: W $/ \mathrm{WI} / \mathrm{H}$ : Treasure Island/HI2: Castaway?/ UB2: that's not correct! Try again!/ HI1: The Book of Life?/HI2: The Jungle Book?/ UB1: CORRECT!/UB2: HI2, you have one point! 


\subsection{Projects}

Throughout the first part of the calendar project, when students of both universities had to collaborate and interact though the tasks described above, they all became acquainted and generated a relationship of mutual trust. Through the different tasks that made the first part of this telecollaboration project, the pre-service teachers obtained information about the tastes and needs of their classmates; they had the opportunity to find out who they were, where they came from, which languages they spoke, when and where they had started to practice Spanish, what language aspects they wanted to improve, etc. This information was very important for the UB pre-service teachers in order to create a meaningful project for the target students. A meaningful final project had to connect with students' interest and with their reality, but which also would help to improve their communicative competence according to their needs.

So, the first part of the telecollaboration project contributed to developing an atmosphere of closeness, which is vital in learning in general but essential in digital learning environments. This way of making digital conversations closer and warmer ${ }^{26}$ is also known as an electronic propinquity which has been described as the sense of proximity, involvement and presence over any digital communication environment, all of which leads to satisfaction towards interaction. ${ }^{27}$ In computer mediated communication, propinquity is expressed and perceived in innovative manners: emojis, humor, 'likes' are relatively new ways of making digital conversations closer and warmer. Propinquity is strongly associated with satisfaction, communication effectiveness, and task accomplishment. ${ }^{28}$

Therefore, as we have already mentioned, in this second phase of the telecollaboration project, pre-service teachers had to take control of the educational process and design a project tailored to their col-

26 Joseph B. Walther and Natalya N. Bazarova. (2008). "Validation and Application of Electronic Propinquity Theory to Computer-Mediated Communication in Groups." Communication Research, 35 (5), pp. 622-645.

27 Felipe Kozernny. (1978). "A Theory of Electronic Propinquity: Mediated Communication in Organizations." Communication Research, 5(1), pp. 3-24, here p. 7.

28 Joseph B. Walther and Natalya N. Bazarova. "Validation and Application of Electronic Propinquity Theory to Computer-Mediated Communication in Groups." 
leagues in Iceland. While designing these final projects, the UB students had to keep in mind that they were supposed to create tasks that would involve the development of digital skills as well as language skills.

Professors from both universities supervised the creation process of every project before the participants started to work on them. First, the pre-service teachers presented their project drafts to their classmates and teachers at the UB. Once they received the first feedback, they shared those drafts with the professor at $\mathrm{HI}$ and together they started to collaborate in order to improve them, aiming for the final version suitable for the HI students. The professors advised the preservice teachers about the evaluation system, task organization, content, digital applications that could be used. The task sequence should imply 14 working hours for the HI students.

Apart from designing that task sequence for the final project, the students at the UB were also expected to get involved in the evaluation process and therefore to create the evaluation grids with the appropriate criteria to assess the HI students' work.

For this phase, five final projects were created by five groups. Students of both universities were grouped together according to this system: two or three students from HI with four or five pre-service teachers from the UB. For clarity, these are the projects created by pre-service teachers from the UB for every student group at HI. Some groups used applications suitable for designing the final project like Padlet walls (group 2 and 5) or geolocators like Zeemaps (group 4).

1. Hispanos en Reykjavik. Web page about the everyday life of Hispanoamerican people in Reykjavík.

2. Mujeres rebeldes. Padlet ${ }^{29}$ about the many women that have served as an inspiration and influenced our world.

3. Esta es mi ciudad. Multimodal touristic guide about Reykjavík.

29 https://padlet.com/. Padlet is an application to create an online bulletin board that you can use to display information on any topic. A detailed description about how this application can be used to teach and learn foreign languages can be found in Pilar Concheiro and María Méndez. (2018). "Uso de herramientas digitales para la escritura colaborativa en línea: el caso de Padlet." Marcoele (27), pp. 1-17. 
4. ¿A dónde vamos? Trip planner with video blog and Zeemaps ${ }^{30}$

5. Si vienes a mi país. Padlet about advices and useful tips for people moving to Iceland to work.

In order to design these projects, it is relevant to emphazise the fact that the pre-service teachers at UB were requested to take into account which students they were going to work with. So, for example, for project number 5, they knew that the two students at HI were concerned about social issues, like proper integration of people moving to other countries, and that their studies at HI were also related to that issue. The five projects wanted to connect with $\mathrm{HI}$ students' interests and studies. They were designed for practicing Spanish as a foreign language, but also to create a final product that would fit in with the students' lives.

\subsection{Evaluation}

As revealed in the introduction, for the students of Spanish as a foreign language at the University of Iceland, the telecollaboration project represented $50 \%$ of the final grade, while it implied $80 \%$ of the final grade for pre-service teachers at the UB. In this article and this section will describe and discuss the evaluation in relation to the $\mathrm{HI}$ students. Even though the experiences of both groups are interesting and deserve a discussion, the focus on this paper will be on HI students' experience and in future papers the other side of tellecolaboration will be explored.

The first part of the project, represented by the three tasks described above, was equivalent to a $30 \%$ of the final grade while the second part of the virtual exchange, where the HI students had to work on the final project designed specifically for them by the UB pre-service teachers, had the value of $20 \%$. In order to evaluate the three initial tasks and the final project designed by the UB students, the following criteria were taken into account:

30 https://www.zeemaps.com/. Zeemaps is a mapping service. It allows to create, publish and share interactive maps. For more information about how to use this application to teach and learn foreign languages see Pilar Concheiro. (2017). "En mi ciudad hay." Der fremdsprachliche Unterricht Spanisch, 35, pp. 4-11. 
a. Participation and involvement in the learning process.

b. Answering on time and respecting delivery dates.

c. Completing the self-reflection diary.

The first two criterias are particularly important in a project like this, as the students do not meet face to face, hence the lack of communication or not answering in time can lead to problems in communication. To avoid this situation, the three professors in charge of the project had, right from the start, to emphazise the collaborative work and the autonomy of the learning process. The three professors from both universities also had to monitor constantly the telecollaboration progress to encourage students, to follow up if goals were achieved and to find solutions if problems arose. They acted like guides and they were expected to "be there", to offer support and in some occasions mediate group/pair works; in other words, to remind the participants that the project's success relied on everybody's participation and involvement. The text below (translated into English by the writer of this article) is an example of this monitoring process done by the teachers. Dr. Olivia Espejel, one of the teachers from the UB, published an announcement in Google classroom that could be seen by all the participants. In the message, she reminded them how important it was to keep up the communication with their colleagues and to report any possible difficulty that could arise to the teachers in charge.

"Dear student. I hope that the projects have started well and you are all in close contact with your colleagues. We advise keeping the communication channels very open and not to forget that close and friendly connection that you have been establishing with your colleagues.[...] Do not hesitate to make the changes that are necessary to adapt to the situations that arise and contact us to be informed about anything that could happen.[...] Greetings and good luck!”

The third criteria, completing the self-reflection diary after each task, had a main purpose which was to foster a reflexive discourse about the learning process. This introspective process was necessary to reflect about what they had learnt during the task and how they have 
felt about it. This reflection is essential for the learner as makes him/ her feel conscious about his/her learning process. ${ }^{31}$ As the objective was to make students reflect on their learning process, they could write their reflections in Spanish as well as in Icelandic or English (used as lingua franca), if they would feel more comfortable doing so. In order to guide their reflection process, the following aspects, among others they could consider relevant, were suggested. Those included: positive and/or negative aspects, role of technology in the learning process, difficulties that may have arisen and linguistic aspects that they have learned or improved through the task they have done.

The pre-service teachers also participated actively in the evaluation of the final project they had designed for the HI students. As it was explained in the section 3.4 of this article, apart from creating the didactic activities they had to develop an evaluation system for them. The different evaluation criteria used to assess every project were taken into account and counted $10 \%$ which is half of the total percentage designated. When the projects were done, the pre-service teachers had to send to the teacher in charge at HI the completed evaluation grids and a report about HI students' performance.

\section{Results}

\subsection{Lexical and grammatical competence}

In their self-reflection diaries, HI students expressed how their grammatical and lexical competence had improved due to their participation in the telecolaboration exchange with the pre-service teachers at the UB. Comments making reference to grammatical and lexical aspects are reproduced here and translated into English.

- "I realized that me gustaría can express future, realized that saber means knowing, learned that oro means gold and campo could mean sports hall".

31 Ma Vicenta González and Joan-Tomas Pujolá. (2007). "El Portafolio Reflexivo del Profesor", in VV.AA.: La biblioteca de Gente 1. Barcelona: Ed. Difusión, p. 438. 
- "I learned new words like albornoz (yes, I was wearing my bath robe during our viodeconference) alquilar, alce and ciervo".

- "I learnt to use the pretérito indefinido and the use of some words from the oral speech like pues, o sea o bueno. I also learnt some new words like grabar, names of countries in Spanish. At the end of the task I felt like I was able to use the past tenses properly".

- "I have learnt a little bit of Colombian slang and some new words like: bosques, encima, ballena, tiburón... I also learnt how to use short versions of some words like finde instead of fin de semana".

- "I have asked the guys in Barcelona about some words that I am interested in learning like, for example, the difference between eso, esto y aquello or between aún and todavía".

- "I learnt new words like harina, rayado, asqueroso" (when we were talking about Opal)".

It is significant that the following student (a heritage speaker ${ }^{33}$ of Spanish born and raised in the USA and used to the linguistic variety of Mexican Spanish) regarding her/his grammar learning, reports to have practised during the telecollaboration project the pronouns and verbs characteristic from the Spanish peninsular variety while also reflecting on the sociopragmatic use of those personal pronouns.

- "I practiced how to use os and sois and I felt very happy about this little grammar lesson. I had never learnt the use of vosotros and I am very happy to use it.[.... K. told me that in Spain tú and vosotros are used most of the time but usted and ustedes are used in more formal situations, like when you talk to your boss or to older people".

32 The word asqueroso means disgusting in English.

33 According to Valdés (1997), a heritage speaker is an individual who was raised in a home where a non-English language is spoken, who speaks or only understands the heritage language, and who is to some degree bilingual in English and the heritage language. Guadalupe Valdés. (1997). "The Teaching of Spanish to bilingual Spanish-speaking students: Outstanding issues and unanswered questions." In María Cecilia Colombi and Francisco X. Alarcón (Eds.), La enseñanza del español a hispanohablantes: Praxis y teoría. Boston: Houghton Mifflin, pp. 8-44. 
We can also observe how the following student reflects on the fact that the topic of the conversation helped him to learn certain vocabulary he did not know and also improved his motivation to keep on practicing in the target language.

- "I have learnt the expression comunidad mundial and more vocabulary related to the glozalization today. I really liked talking about this! I want to chat more with my colleagues from Barcelona about it".

- "During our final project we had to talk about topics like night life, monuments and interesting places to visit so I learnt very interesting words related to it, like for example, ambiente caluroso. My colleagues at Barcelona explained to me the grammar mistakes I made, for example, the tense concordance and they told me how I could improve".

\subsection{Pronunciation}

The students at HI also indicated that the participation in the telecollaboration project had helped them to improve their pronunciation in Spanish.

- "Y. corrected me and told me how to pronounce some words that were so difficult for me".

- "My Spanish has improved after talking to M. and P. I feel that my pronunciation and intonation got better".

- "She helped me to pronounce some words and sounds that were so difficult for me. Words like vegetariana, adjetivo or arroz (we were talking about the best way to cook paella)".

The telecollaboration project provided a digital learning environment where students of Spanish as a foreign language could be exposed to different accents characteristic of the Hispanoamerican world. 
- "I'm so glad that L. and K. are from different Spanishspeaking countries. L. is from Argentina and K. is from Spain. They speak with a different accent and they pronounce the same words in very different ways. That's not a problem but just a bonus because I have the opportunity to get used to two different types of accents".

\subsection{Fluency}

Students at HI considered that the virtual exchange project had also helped them to be more fluent in the target language.

- "After completing the last task of our final project and all this time together I felt that speaking in Spanish was not that difficult as before, actually I think it is really easy!”.

- "I feel that words come easier and I'm not constantly using the dictionary".

- "Now I think that I communicate in Spanish in a more natural way. It's not just that I learnt the past tense in a class, it's that I used it!"

- "I found out that I have been learning new words and sentences unconsciously".

\subsection{Confidence}

Confidence is very important for foreign-language learners because it empowers them to communicate and produce in the target language. Gains in confidence are regularly reported by participants in virtual exchange projects ${ }^{34}$ and this telecollaboration project has not been an exception.

- "I always remember the first class when the teacher explained to us how this project was going to be and I thought that I would not be able to do it, I'm a very shy person. I thought

34 EVALUATE (2019). 
that it was too far away from my comfort zone. But I managed to do it and I learned loads of things and new words".

- "I feel more confident when I speak and I've noticed that I can express myself better than before I started this project".

- "I had not used my Spanish in such a long time so to be honest, I was very scared before the first videoconference, but my colleagues at Barcelona were so nice that afterwards I felt great speaking in Spanish again”.

After analysing all the reflexive diaries, and although in this article we concentrated the four indicators described in the subsections above, we found it relevant to include in this article other aspects that are part of the linguistic competence of a language user like the sociocultural knowledge. HI students had the opportunity not just to practice the target language with the pre-service teachers at the UB but also to find out useful sociocultural information. They could see the culture and society through the eyes of their colleagues in Barcelona.

- "It was interesting to get an overview of music in the Spanishspeaking world. It was nice to get recommendations about certain bands. It surprised me that the Spanish rap sounded like the American and Icelandic one. It was great fun to talk to E. and M. about the instruments played in flamenco. I also thought it was amazing to find out that the Macarena song by Los Del Rio is still played in parties in Spain despite being so old fashioned and totally uncool. It was also very funny to tell them that I learned that song when I was small."

- "I learned a lot about Spanish history and all the changes in Spanish society. I didn't know anything about it."

The exchange project also contributed to developing an intercultural perspective among the students and even contributed to changing their world's perspectives and values. 
- "I loved the video they made in task 2!! I love cooking and tasting new food and I learned that the Colombian arepas $^{35}$ are made with corn flour as in Mexico. Then I realized that in Russia we have a similar dish, but we use wheat instead of corn."

- "In the final project we had to choose an important woman in our lives and talk about her. It could be somebody that contributed to a change in society, somebody that inspired us, or just somebody we love. I chose my grandmother. She is born in Norway in 1920 and fought against the male-dominated world she lived in. She went to university and she became a teacher. This project has made me think so much about my power as a woman. It has changed my world perspective \# mujeres rebeldes ${ }^{36 "}$

\section{Conclusions}

On the whole, the students' reflections suggest that the virtual exchange project had a positive impact on their foreign language competence development as well as their learning language process. According to their self-reflections, they learnt about culture and society of the target language while simultaneously reflected on their own identity. However, given the limited number of participants, further research is needed in order to analyse the learning gains from these exchanges using quantitative research methodologies. However, in order to conduct further study, exchange activities need to be integrated in language courses to provide a suitable digital learning environment to practice the target language. It is essential to maintain stable institutional partnerships which enables telecollaborative exchanges to be repeated year after year and thereby become an integral part of course syllabus and the teachers' work practices.

In order for telecollaboration to make a significant impact on university education and to be sustainable in the long-term, it is important that the activity achieves a considerable level of integration in curricula. Online learning activities such as telecollaboration need to

35 Arepas is a type of food made of maize dough and typical from Colombia and Venezuela.

36 The student uses the hashtag belonging to one of the tasks they were working on the final project. 
move from being a peripheral activity to being widespread practices which are well-known and highly-valued by university educators and management. ${ }^{37}$

As a limitation for this study and future improvements to consider, it is necessary to mention the constant follow-up that the teacher must do in order to check the students' participation and task fulfilment. The teacher's role as a guide was essential for this type of project. Also, for future editions, we have discovered that it is really important to give some practical workshops or dedicate some time just to show them the features of some digital applications that will be used during this telecollaboration project to foster digital competence among students. That was the case of the WhatsApp instant messaging service that is so spread out in Spain but not that much in Iceland. So, just to give an example to illustrate this situation, students at HI took a really long time to reply to their colleagues at UB and when they were asked about the reason, they answered that they were more familiar with using messenger than this "new" app. Another example is that they did not explore all the Flipgrid features, the application used in the first task, for themselves and did not use them when they recorded their videos.

As a representative closing remark, I will conclude this article by quoting one the reflections of a student from the University of Iceland. I would like to leave those words in Icelandic, in the original version they were written. ${ }^{38}$ Those words sum up perfectly this project because they express gratitude towards teamwork and a willingness to keep on learning a language through a virtual learning exchange.

- $\quad$ "E., M. og hinar stelpurnar eiga hrós skilið. Pau voru mjög almennileg og skemmtileg, skilningsrík og alltaf tilbúin að hjálpa. Svona "jafningjafræðsla” er mjög sniðug. Ég myndi hiklaust mæla með pessari kennsluaðferð. Vonandi verður pessi hugmynd innleidd við kennslu fleiri tungumála við HÎ."

37 Robert O'Dowd. (2013). "Telecollaborative Networks in University Higher Education: Overcoming Barriers to Integration." Internet and Higher Education, 18, pp. 47-53.

38 Translation: Elena, Miguel and the other girls deserve praise. They were very kind and fun, understanding and always ready to help. Such "peer education" is very clever. I would sincerely recommend this teaching method. Hopefully this idea will be implemented in teaching more languages at UI. 


\section{Telecollaboration HI-UB: online interaction and exchange in a language course}

This article presents an online interaction and exchange between Icelandic learners of Spanish as a foreign language from the Faculty of Languages and Cultures at the University of Iceland, that followed the course SPÆ267G Conversation II or Talpjálfun II: Fjölmiðlar og bversdagsmenning, taught during the 2019 spring semester, and preservice teachers of Spanish studying their Master's degree at the University of Barcelona (sp. Universidad de Barcelona). This telecollaboration project was based on different communicative tasks that had to be completed collaboratively using different formats of online interaction (videoconferencing, WhatsApp, Flipgrid). Task designing and evaluation systems used in this project are presented in the article as well as the qualitative methodology that was applied in order to analyze HI students' reflections on the telecollaboration project and its impact on their language competence.

Keywords: telecollaboration, students' reflections, language competence 


\section{Netsamskipti milli HÍ og UB: samskipti og samræður í tungumálanámi}

Í pessari grein verður kynnt námskeiðið SPÆ267G Talbjálfun II: Fjölmiollar og bversdagsmenning sem kennt er 1 fjarnámi milli Íslendinga í spænskunámi við Háskóla Íslands og nemenda við Háskólann í Barcelona (sp. Universidad de Barcelona) sem eru að ljúka meistaragráðu sem spænskukennarar. Námskeiðið var kennt á vormisseri 2019. Gerð verður grein fyrir æfingahönnun og námsmati í fjarnámsverkefninu sem byggist á mismunandi samskiptaæfingum í gegnum fjarfundabúnað, Whatsapp og Flipgrid. Kannað er með eigindlegum rannsóknaraðferðum hvaða áhrif pessar aðferðir höfðu á tungumálafærni nemenda og hver viðbrögð peirra og viðhorf til verkefnisins voru.

Lykilorð: rafræn samskipti, viðbrögð nemenda, tungumálahæfni 